\title{
GOLD-PLATED PINS OF THE GREAT MIGRATION PERIOD IN BOHEMIA
}

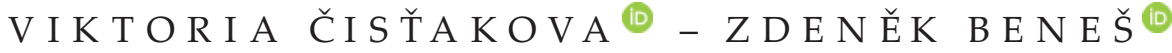

\begin{abstract}
The gold-plated iron pins from the Great Migration Period belong to the rare finds, not only in Bohemia. The loose find from Tehov, distr. Prague-East, was therefore a surprise. Together with examples from Praha-Dejvice, Mochov and Chotěšice it belongs to the Thuringian-Bohemian group of pins, which can be dated to the turn of $5^{\text {th }} / 6^{\text {th }} \mathrm{c}$. until the $2^{\text {nd }}$ third of $6^{\text {th }} \mathrm{c}$. Nevertheless, all of the datable Bohemian finds belong to the phase E1 of the Danubian periodisation. It reflects the specific relationship of Thuringia and Bohemia in this period, along with a number of fibulas and other artefacts. Gilded pins from Bohemia are good example of gold plating technique. The results of X-ray fluorescence proved that the gold used for gilding is of very high purity (89-93.2\%). This is characteristic for jewellery made in Barbaricum during the Roman and the Great Migration Periods. The sources of that gold are usually sought in imports from Roman or Byzantine Empires, especially in the solidi coinage. The gold-plated iron pins are mostly not preserved in their whole length, because the iron part (roughly a half) has deteriorated. It is proved that tapered, corded end is in fact the head part of the pin, not the lower end. The function of these pins as a hair decoration is supported by the gold plating, because the item is too fragile to use for ordinary cloth fastening. Solitary hair pins were used exclusively by women in Frankish, Baiuvaric, Alemannic, Thuringian and Langobardic areas. The gold or gilded examples belong to rare finds and in the majority of them was found in elite graves.
\end{abstract}

Keywords: Bohemia, Thuringia, Great Migration Period, gold-plated pins.

\section{INTRODUCTION}

In the recent years there is an increasing number of archaeological items found by metal detectorists. Some of them belong to unique or rare types. This is the case of the presented object which was found by a young metal detectorist on 11. 6. 2020 in the woodland area southeast from Prague in the cadastral unit of Tehov u Řićan, distr. Prague-East. ${ }^{1}$

The iron pin plated with thin golden sheet and decorated with transverse ribs and faceted squares had been found $25 \mathrm{~cm}$ deep in the forest soil next to a pathway. During the subsequent surface metal detector prospection, no other prehistorical artefacts were found. Since the region corresponds to an upland woodland area with scarce archaeological sites, we consider the pin to be a loose find. The artefact is remarkably well preserved (probably due to the deposition in the forest soil, not in the ploughland) and it has been consequently professionally conserved.

\section{BOHEMIAN FINDS}

This accidental find from Tehov $\mathrm{u}$ Říčan does not represent a unique appearance of a gold-plated pin in Bohemia, however it is one of the few exemplars of this type (see below the Finds Catalogue; Fig. 1). The first of them had been recovered in 1893 by the famous amateur archaeologist J. A. Jíra in burial no. XIV at the Mailbeck's brickwork in Praha-Dejvice (Fig. 2: 3; 3: 3). The rich female burial contained,

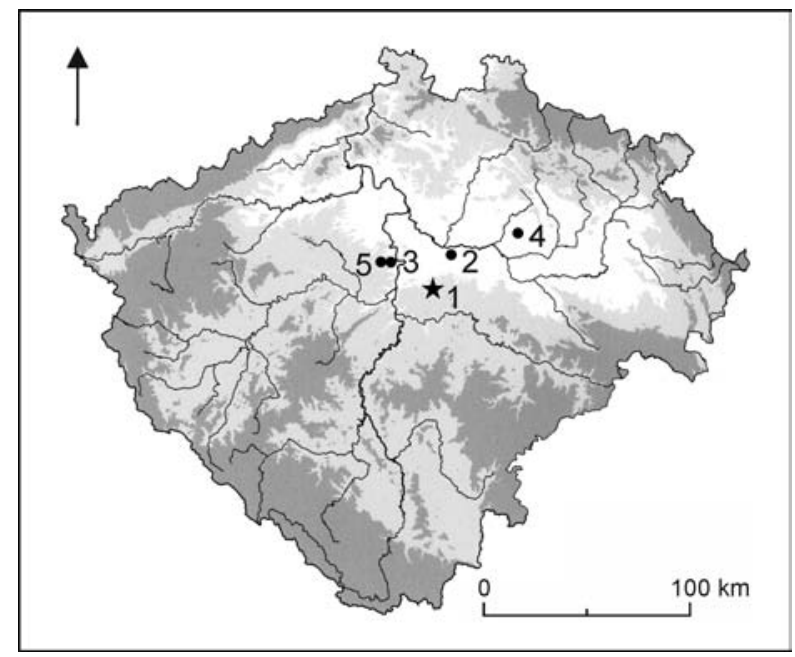

Fig. 1. Map of the gold-plated pins of the Great Migration Period in Bohemia. 1 - Tehov; 2 - Mochov; 3 - Praha-Dejvice; 4 - Chotěšice; 5 - Praha-Ruzyně.

\footnotetext{
1 We thank our colleagues and friends, David Daněček and Juraj Hríb, who ensured the contact information and find circumstances. Most of all, we sincerely thank the finder, Tomás Štefka, for his exemplary approach to our archaeological heritage. This work was financially supported by Ministry of Culture of the Czech Republic (DKRVO 2019-2023/17.III.a, National Museum, 00023272).
} 


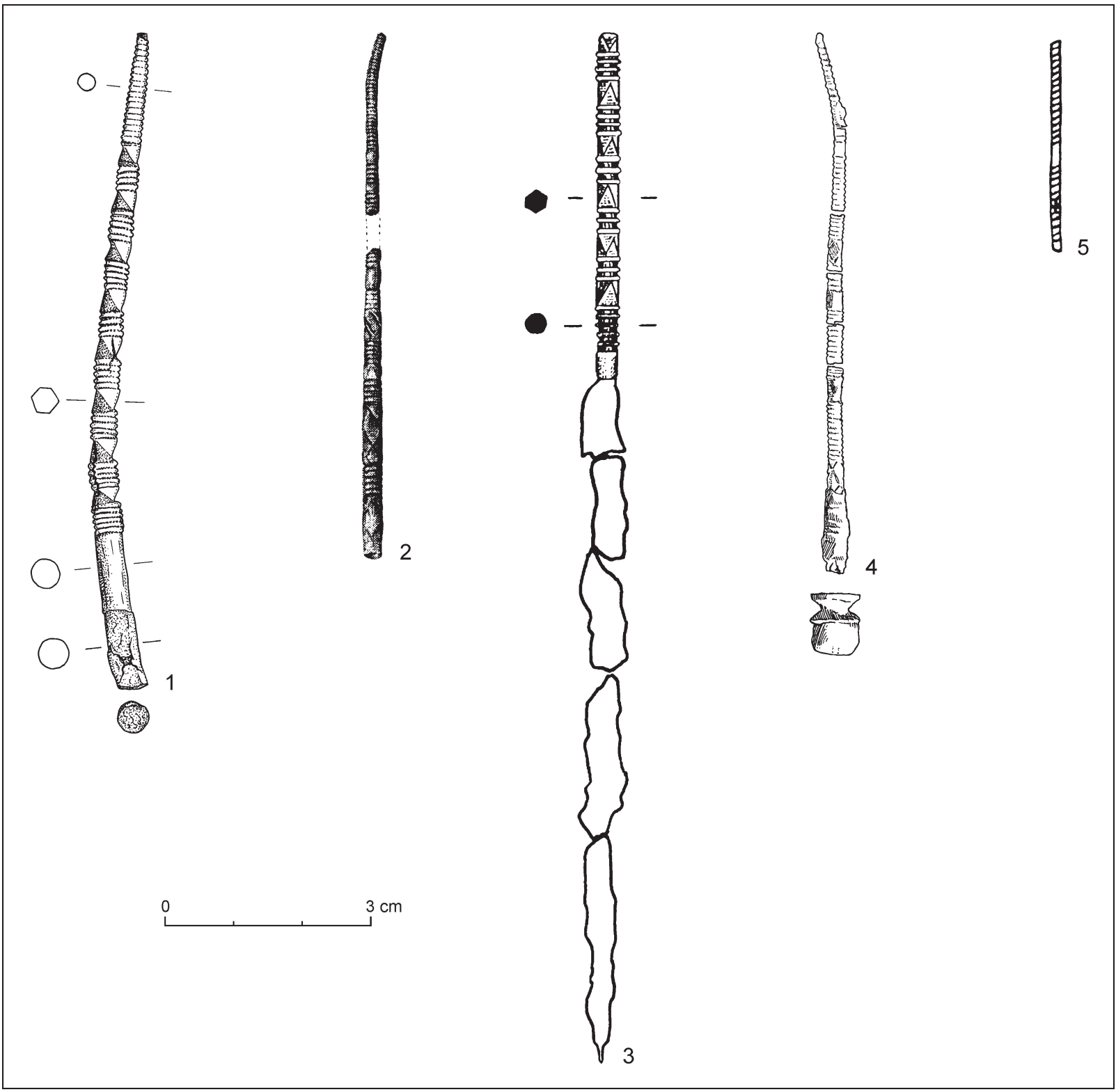

Fig. 2. Gold-plated iron pins in Bohemia. 1 - Tehov (drawing by I. Vajglová); 2 - Mochov (Zeman 1958, fig. 14: 7); 3 - Praha-Dejvice (Urbanová/Kostka/Korený 2010, fig. 4: 6); 4 - Chotěšice (Hellich 1919, fig. 9: 1); 5 - Praha-Ruzyně (Kuchař́k et al. 2008, fig. 10: 7).

apart from the gold-plated iron pin, a large amount of other grave goods, such as the forcipated (Zangenfibel) fibula of the Straß type (look at thorough analysis in Urbanová/Kostka/Korený 2010, or Losert 2003, 113-115, distribution map 9). On the basis of the preserved finds, grave no. XIV can be dated to the turn of $5^{\text {th }} / 6^{\text {th }}$ and the $1^{\text {st }}$ third of $6^{\text {th }} \mathrm{c}$. Due to the fibula and iron shaft of a folding chair, the deceased noble woman of burial no. XIV might have been connected with the Franco-Alemannic area. If we focus more on the gold-plated iron pin from this grave, we must admit that the comparison to the find from Tehov is possible only in some features: the pres- ence of thin golden plating which is ornamented (embossed) in the same manner. On the other hand the Praha-Dejvice piece does not have the slightly tapered termination ornamented by the transversal ribs and the most of the original length of the pin, if we can rely on the original documentation, was not gilded, but made of bare iron (Hlava 2010, fig. 6; Urbanová/Kostka/Korený 2010, fig. 2; 4: 6).

The gold-plated pin from burial no. 12 at Mochov is a quite accurate analogy for the find from Tehov. It is almost identical regarding the size and the ornamentation. However, the difference lies in differently formed lower part of the pin which has a plain 


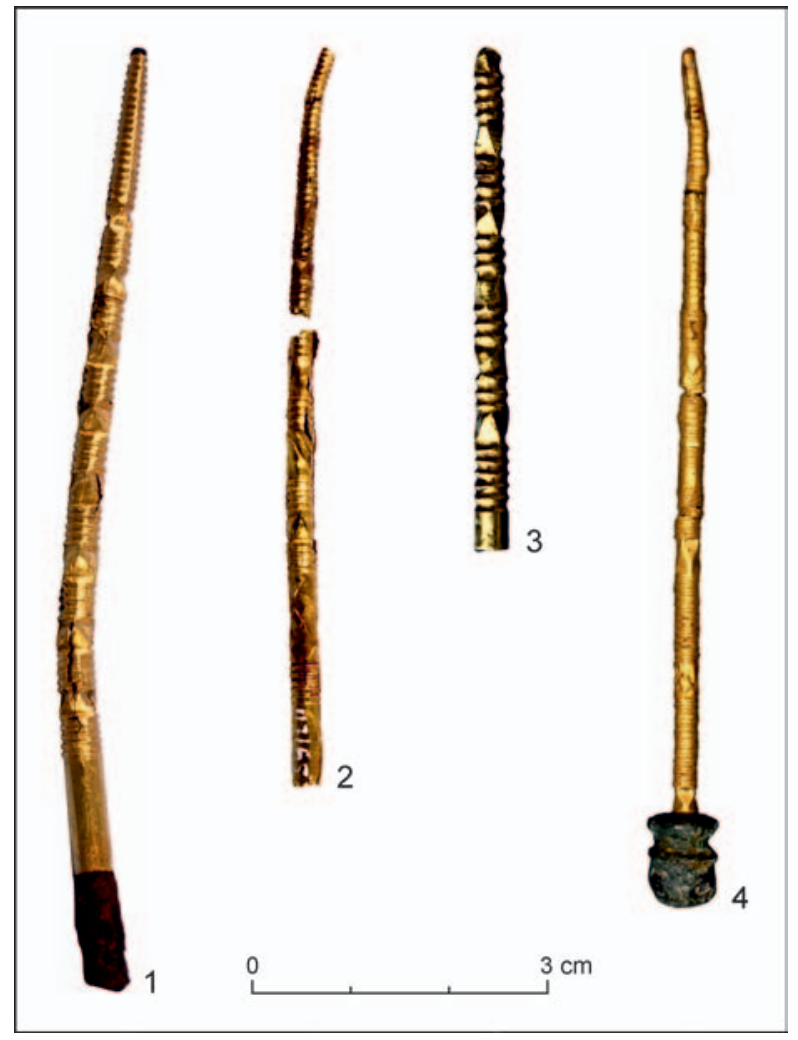

Fig. 3. Gold-plated iron pins in Bohemia. 1 - Tehov (photo by R. Kozáková); 2 - Mochov (photo by R. Kozáková); 3 - Praha-Dejvice (Hlava 2010, fig. 6); 4 - Chotěšice (photo by Z. Beneš).

section and is ornamented by diamond-oriented grooves (Fig. 2: 2; 3: 2). Although the grave no. 12 was robbed a $S$-shaped fibula with bird heads was found (Zeman 1958, 436, 437, fig. 14; 21: 2; 22: 5) along with the gold-plated pin and other grave goods. This fibula belongs to the so-called Naumburg-Mochov type, which includes pieces with clockwise oriented body and closed beak (Tejral 2002, 335, 336). Alternatively, it responds to the Stößen type (Losert 2003, 174-177) in different works. Whether we use this or that name, the chronology and distribution is certain - they are quite early types of S-shaped fibulas, occurring mostly in Thuringia, Alemannia and Bohemia at the end of the $5^{\text {th }} \mathrm{c}$. The closest analogous find in Bohemia can be found in PlzeňDoudlevce (Losert 2003, 175, 176, distribution map 21; Svoboda 1965, 159, 257, pl. LXVI: 3, 4).

Another close analogy to the find from Tehov comes from the burial no. 1 from Chotěšice. ${ }^{2}$ It is an old find from a grave that was disturbed by construction of a road in 1912. The pin has similar features as the pins described above, although it differs in few details (Fig. 2: 4; 3: 4). In the original publication, J. Hellich records that the pin was preserved with a 'massive bronze gilded head' (Hellich 1919, 34). The traces of gilding are no more visible by the naked eye today. It is quite striking that the massive heads like this were not found during excavations of the previous graves in Praha-Dejvice and Mochov. Another point is that the pinhead from Chotěšice resembles the decorative buttons known from fibulas dated to the late phase of the Great Migration Period (Phase E1 and E2 according to e.g. Droberjar 2008, tab. 1) both in size and shape. It is not exceptional for the contemporary cemeteries in Central Europe that during the grave robbing, some pieces of jewellery fell off and were lost by the robbers, especially if this condemnable deed had been done during the night. As an example, we can mention the burial no. 1 from Mochov cemetery, where such knob of a fibula had been found (Zeman 1958, 428, fig. 5: 3). Therefore, it seems probable that the reconstruction of the pin in the published works is incorrect. ${ }^{3} \mathrm{We}$ must however admit, that similar pinheads can rarely appear - as is shown by an example of a pin from Alemannic necropolis at Basel-Gotterbarmweg (Martin 2002, fig. 6: 33) - but hardly could be made of a different metal.

The last gold-plated iron pin comes, in contrast to the previous examples, from a settlement situation. During the rescue excavations in Prague-Ruzyně, this find has been recovered from the circular ditch dated to Late Bronze Age (feature 320; Kuchařík et al. 2008, 206, 224, fig. 10: 7). This short and equally narrow fragment is ornamented by transversal (or a bit oblique) ribs only. It does not fit very well with the above-mentioned examples and it is quite probable that it represents a different type of pin. An uncertain find of another gilded pin may have come from Patokryje (Most district) in northern Bohemia, but the circumstances of its recovery are nebulous. There is a possibility that the Merowingian (female) grave had been dug into the Corded Ware culture mound (Korený 2008).

\section{TECHNOLOGY OF PRODUCTION}

In the context of Barbaricum during the first millennium CE, gilding technique was frequently used by goldsmith workshops for decoration of variety of items. One of the basic techniques is gold plating, when the gold foil is fixed mechanically to the

\footnotetext{
2 The authors would like to thank Mgr. A. Lamprecht, archaeologist and curator of archaeological collection in Polabí Museum in Poděbrady, for allowing us to study the pin from Chotěšice personally.

3 This pin is currently displayed in Polabí Museum in Poděbrady with the head glued on the pin.
} 

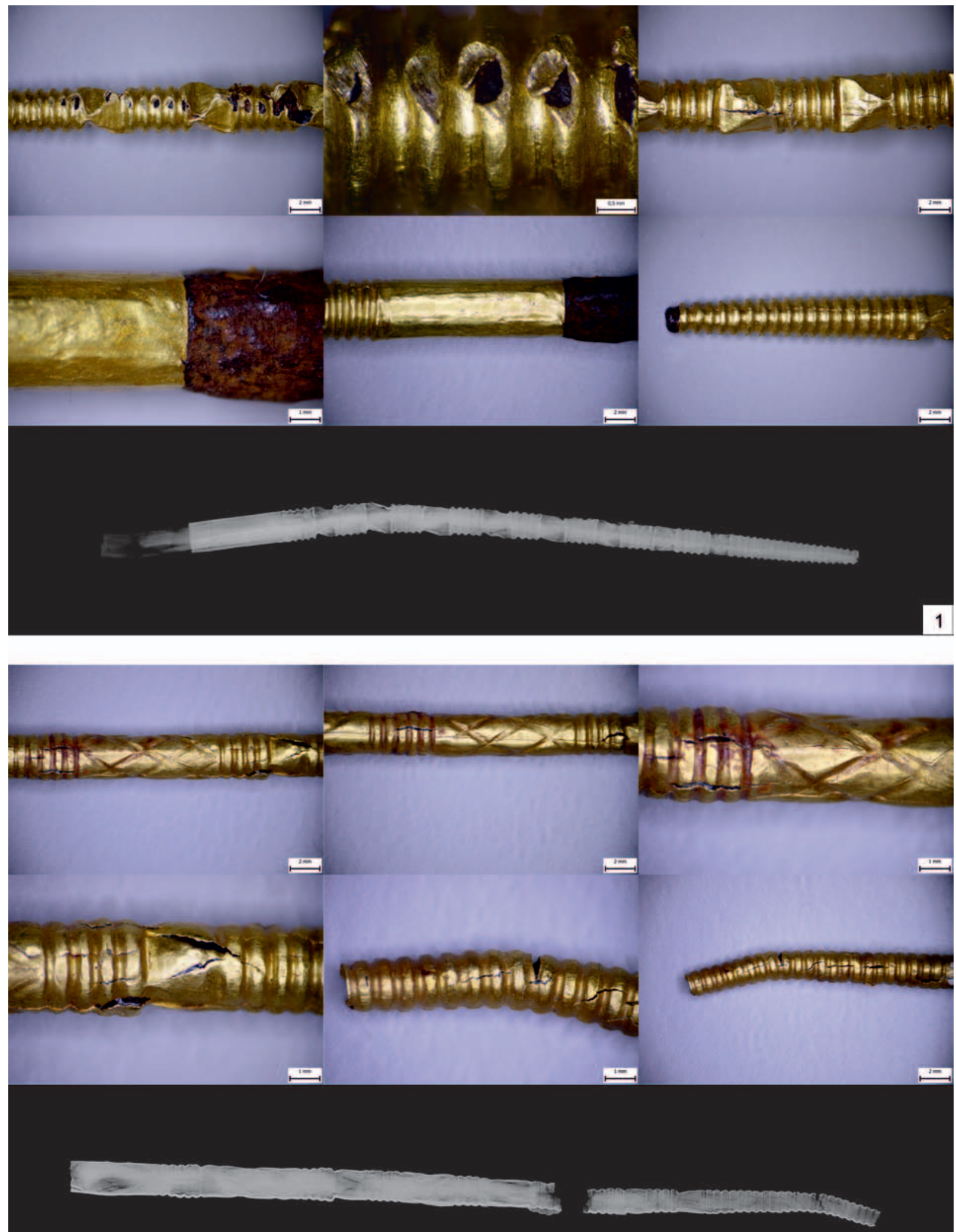

Fig. 4. Technological details of the gold-plated iron pins - macro photos and X-ray pictures. 1 - Tehov; 2 - Mochov (photos and RTG by R. Kozáková and J. Krejčí). 
substructure. For plating it is necessary to use a thicker gold foil. The main disadvantage of this technique are the visible joints that cause a weaker connection between the components and afterwards corrosion of the base material (Aufderhaar 2009, 244). The gilded pins from Bohemia are good example of gold plating technique. On macro photos of the pins from Tehov and Mochov, the original seams are clearly visible. On Mochov pin there is a geometric chasing ornament that could have been made by a stylus or a puncher (Fig. 4: 2). As we can observe on X-ray photo, the iron core is deeply corroded and, in some parts, only the gold foil is preserved.

Items decorated with silver and gold foils were produced in Barbaricum since the Roman Period. Development of the goldsmith production occurred at the end of Early Roman Period and the beginning of Late Roman Period, when sophisticated decorative techniques started to be applied (filigree, granulation and decorative foils; Natuniewicz-Sekuła 2017, 201). Gold and silver foils were applied mainly on bronze and iron fibulas, however other personal objects as belt fittings or spurs and weapons could also be decorated in this technique (von CarnapBornheim 1994, 100). The gold foil could be additionally decorated and shaped. Gold or silver foils could be pressed on special matrix and decorated with punches. Another way was to put smooth foils on a layer of wax or lead and then manually chase or press the final pattern with a thin stylus or punch (Natuniewicz-Sekuła 2017, 209; 2019, 303). For example, both smooth and stamped foils were widely used during Late Roman Period on silver, iron and copper alloy base; however, the diffusion bonding method, which was used for gilding silver sheets, became more popular. During the Great Migration Period, predominantly the fire gilding technique was used, since it allowed to decorate items with deeply profiled surfaces (Aufderhaar 2009, 246-248). However, the old-fashioned plating with impressed gold foil was still in use, e.g. for personal decorations as our pins, or it could be find, on other luxurious items, such as the silver strainer from a rich Langobardic female grave from Vörs (Menghin/Springer/ Wamers 1987, 582, pl. 92).

The results of $X$-ray fluorescence method (Tab. 1) show the use of metal of very high purity. ${ }^{4}$ The average content of $\mathrm{Au}$ was for Tehov pin $89 \%$ and for Mochov pin 93,2\%. Gold of a high fines (between 90-98\%) is well known from the jewellery made in Barbaricum during the Roman and the Great Migra-
Tab. 1. Results of XRF analysis of the gold-plated iron pins from Tehov and Mochov (analysed by R. Kozáková, National Museum, Prague).

\begin{tabular}{|c|c|c|c|c|c|c|c|c|c|}
\hline & 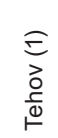 & $\begin{array}{l}\widehat{d} \\
\text { ठ } \\
\stackrel{0}{\omega}\end{array}$ & $\begin{array}{l}\widehat{0} \\
\text { o } \\
\text { 吕 }\end{array}$ & 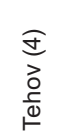 & $\begin{array}{l}\mathscr{D} \\
\mathbb{\pi} \\
\frac{\pi}{\omega} \\
\stackrel{\pi}{<}\end{array}$ & $\begin{array}{l}\text { E } \\
\text { O } \\
\frac{1}{0} \\
\stackrel{0}{\Sigma}\end{array}$ & $\begin{array}{l}\text { త্ } \\
\text { o } \\
\frac{1}{0} \\
\stackrel{0}{\Sigma}\end{array}$ & $\begin{array}{l}\widehat{0} \\
\text { o } \\
\frac{0}{0} \\
\stackrel{0}{\Sigma}\end{array}$ & 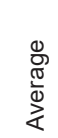 \\
\hline $\mathrm{Au}$ & 88.4 & 89.6 & 88.9 & 82.7 & 89.0 & 95.4 & 92.8 & 91.5 & 93.2 \\
\hline $\mathrm{Ag}$ & 7.7 & 7.6 & 7.2 & 6.9 & 7.5 & 3.7 & 4.1 & 4.4 & 4.1 \\
\hline $\mathrm{Cu}$ & 1.1 & 1.2 & 1.1 & 1.6 & 1.1 & 0.4 & 2.3 & 2.8 & 1.8 \\
\hline $\mathrm{Fe}$ & 2.8 & 1.6 & 2.1 & 8.9 & 2.2 & 1.5 & 1.1 & 1.1 & 1.2 \\
\hline
\end{tabular}

tion Periods (Natuniewicz-Sekuła 2017, 189; 2019, 299). ${ }^{5}$ The sources of gold could be found on the territory of Barbaricum, but imports from the Roman Empire and later from the Byzantine Empire are considered to be the prevalent source of gold for Germanic area (Quast 2013). The most credible is the theory of transporting gold and silver coins as a raw material for goldsmith needs (Aufderhaar 2009, 249). For the Great Migration Period, the main source of high purity gold for Germanic tribes were solidus coins (nomisma). As is known, the late Roman authorities bought loyalty of barbarian elites with great amount of gold items and coins. It is logical that surplus of golden coins had been used to produce jewellery or other elite insignias (Droberjar 2001, 522; 2013, 286). Silver and copper are the most common added elements in gold alloys and their addition was most probably intentional, in order to improve the technical properties of the alloy (NatuniewiczSekuła 2017, 190).

\section{THE CENTRAL EUROPEAN CONTEXT}

While looking for analogous finds all around Bohemia, one fact is quite striking - there is no example of this kind of gold-plated iron pin in Moravia (e.g. Tejral/Peters/Loskotová 2011). The habit of wearing hair pins was not unknown to the wealthy Langobard women in Pannonia (Tomka 2005, 251, fig. 6:3, note 29; Werner 1962, 82, 157, 158), but it concerns bronze or silver specimens, not gilded ones. As we move along the Danube river to the west into Bavaria, we find more examples of hair pins. In the graves of the late $6^{\text {th }}$ and $7^{\text {th }} c$. at Altenerding there are different types of pins - most of them are made of bronze and are of later date. Yet, their ornamentation resembles that of the Bohemian finds from the turn of the $5^{\text {th }} / 6^{\text {th }} c$.

\footnotetext{
4 Analyses were made with XRF analyser Delta Professional by Romana Kozáková, 2. 8. 2021, National Museum, Prague. For detection of metal elements measurement for 30 seconds, for heavier elements and 90 seconds for lighter elements was applied. The measurements were taken on four and three places in order to prevent distortions.

5 For example, the golden pin from Erfurt-Gispersleben has Au concentration near 95\% (Timpel 1980, 205).
} 
(Losert 2003, 49, 50). Quite similar, even in technological point of view, is the silver-plated iron pin from burial no. 753 (Losert 2003, fig. 1: 1). Those specimens were dated by R. Christlein to the $2^{\text {nd }}$ and $3^{\text {rd }}$ third of $6^{\text {th }} \mathrm{C}$. and - which is more interesting in relation to the Bohemian finds - he regarded them as followers of iron gilded pins, which had spread from Thuringia (according to Losert 2003, 49). ${ }^{6}$ We should therefore turn ourselves in this direction.

The graves of early Thuringians offer us relatively rich source of material culture to compare. Since the first Elbe-Germanic wave at the beginning of the Roman Period, Thuringia and Bohemia became closely connected regions (Schmidt 1961, 173; Svoboda 1965, 29-34, 224). We will concentrate on the phase E1 of the Danubian periodisation (e.g. Droberjar 2008, tab. 1) which can be synchronized with the Central German phase IIb (Schmidt 1961). That is also the datation of the burials from PrahaDejvice, burial no. XIV, and Mochov, burial no. 12. B. Schmidt knew several hair pins types - from plain bronze, gold plated silver, gold plated iron and golden pins. All of them are decorated by transverse ribs and facetted cubes, which correspond in striking accuracy to the Bohemian finds and are dated to his phases IIb and III (Schmidt 1961, 139). To the Schmidt's phase IIb we can name just a few examples, e.g. silver gilded pin from Elstertrebnitz, burial 9, which is $18.5 \mathrm{~cm}$ long (Schmidt 1976, 163, pl. 202). ${ }^{7}$ The exquisite chariot burial from grave no. 41 at Erfurt-Gispersleben cemetery can be probably dated to the same period. This female burial contained a golden pin of the same ornamentation which is known from Bohemia (Timpel 1980, 205, $206,227,228$, fig. 17: 17). Other examples fall into the next phase III - e.g. the gold-plated iron pin from burial no. 1 at Beuchte (Schmidt 1961, fig. 10: i), the gold-plated iron pin from burial no. 2 at WeimarNordfriedhof (Schmidt 1961, pl. 45: f; 1970, 75, pl. 73: 2c) or silver-plated iron pin from grave no. 2 at Oberwerschen (Schmidt 1961, pl. 77: g).

A similar, yet still a bit different (e.g. in the manner of ornamentation, different metal use, and later chronology) pins are known from Baiuvaric burials at München-Aubing, Upper Bavaria (Dannheimer 1998, 109, pl. 24: F5) and Straubing-Bajuwarenstraße, Lower Bavaria (Geisler 1998, 69, 70, pl. 65). We know them from Alemannic cemeteries, as Schwabmünchen, Swabia (Babucke 1997, fig. 264), or from the Frankish Rhineland, like Rübenach (Neuffer-Müller/Ament 1973, 80, 81, 162, pl. 2: 30: 10b) and Junkersdorf (La Baume
1967, 105, 106, 246, pl. 32: 514: 1). It must be pointed out, however, that these examples are usually made from plain bronze or silver, and only exceptionally from gold-plated iron. Their ornamentation differs and can be dated to Schmidt's phases III and IV (advanced $6^{\text {th }}$ and $7^{\text {th }}$ c.; e.g. Dannheimer $1962,58-60$ ). ${ }^{8}$

\section{HAIR-PINS \\ IN A LATE GERMANIC COSTUME}

Solitary hair pins are known from Alemannic and Frankish environment, where they became popular during the $4^{\text {th }} \mathrm{c}$. For the Great Migration Period, solitary hair pins are exclusively female jewellery that was used in Frankish, Alemannic, Thuringian and Langobardic areas (Martin 1991, 50; Tomka 2005, 251). There are longer pins (15-20 cm long), in most cases located next to the head with spike headed outwards (Timpel 1980, 227, 228). For the solitary hair pins, the position on the right side of the head is predominate. Another position of the pin is under the head or in the upper part of it. Based on the position of the pins, J. Möller (1982, 19-26) suggested the possible appearance of the female hair style. The theoretical inspiration in Roman provincial hair style is disputable. Moreover, the use of a hair pin is known in the Germanic tradition since the Early Roman Period (Beckmann 1966). Bronze and iron hair pins could be found in ordinary equipped female graves, on the other hand, gold or gilded pins are characteristic only for the elite graves. In that case, the golden (gold-plated) pin could be an indicator of a high social position of its owner (Timpel 1980, 228). Despite the fact that the hair pins are mainly found in the adult female graves, there are several exceptional finds from Langobardic area where pins were found also in the children burials (Möller 1962, 34).

In the western Germanic area, the longer solitary pins became a popular hair decoration and were in use until the $7^{\text {th }} \mathrm{c}$. (Merkel 2004, 113, 114). Most of these pins are bronze, several silver examples are known from richer burials, and usually have a very simple decoration (Rupp 2005). At the beginning of the $7^{\text {th }}$ c., richly decorated pins started to be used for fastening the upper cloth (Martin 1995, 50-52). The cloak pins could be found either on the breasts, belt area or in the lower part of the body. These pins sometimes appeared together with fibula and could possibly fix the upper garment - cloak or overcoat. The majority of cloak pins was found in adult female

\footnotetext{
${ }^{6}$ Original publication of R. Christlein was not available to the authors of this contribution.

7 Dated by, among others, S-shaped fibula of Naumburg-Mochov-Stößen type.

8 There are in fact another pin types and even some that could be predecessors of Thuringian-Bohemian gold-plated exemplars, as e.g. type Fécamp (Böhme 1974, 35, fig, 12: 1, list of finds 9).
} 
burials however the pins could sometimes be a part of grave goods in the juveniles and older infant burials (Gutsmiedl-Schümann 2014).

At the end of the $6^{\text {th }}$ and the beginning of the $7^{\text {th }} \mathrm{c}$. in the area of the western Germanic tribes the combination of two small hair pins (usually with a larger head) got into fashion (Martin 1995, 52). ${ }^{9}$ The custom to cover head with a longer veil probably came to barbarian environment from the Mediterranean area (Möller 1982, 16). Shorter pins usually with polyhedric head are known from the Late Roman graves and were in use during the Migration Period. Based on the location next to the head, the pins were used to fix the veil..$^{10}$ This popular fashion element is well attested in the Late Antique/Early Christian iconographic sources. The court ladies on the mosaic from basilica of San Vitale (Ravenna) are covered with large veils or cloaks, similar veils are worn by the holy martyrs depicted on mosaic from San Apollinare (Ravenna). Another example of this style are the veiled female figures on mosaics from the Late Roman villa rustica in Noheda (Spain). The perfect illustration of a female fashion from the $6^{\text {th }} / 7^{\text {th }}$ c. are drawings from Ashburnham Pentateuch (Codex Turonensis). Interesting examples of a female headdress can be found on the luxury gilded glass bowls dated to the $4^{\text {th }} \mathrm{c}$. from Dunaszekcsó and Intercisa in Pannonia. The depicted ladies wear a special bonnet (headgear) or a specially arranged veil (Urbanová 2015, 218). In the Early Medieval Period veil became an essential part of the female costume. In the Stuttgart Psalter is a depiction of a female figure with a coat pulled over her head and tightly fastened with a large brooch (Martin 1991, 630). A similar fashion is seen on female saints from the Lombard Temple in Cividale del Friuli. The habit of wearing a veil is reflected also in written sources, according Lex Salica the forcible removal of a female head covering used to be punished by law. In Lex Baiuvariorum were mentioned hair pins that were used by married women to fix their veils (Möller 1982, 15, 34).

The combination of two smaller hair pins could be accompanied by one bigger pin that was used for cloth fastening (Martin 1995, 52). The bigger pin could fasten either the cloak or a part of the spacious veil as it is presented on the queen Arnegunda's cloth reconstruction (Martin 1991, 647, fig. 12; Möller $1982,18)$. Other two smaller pins with large spherical heads were found next to Arnegunda's head and originally were used to fasten the veil. The presence of veils is also documented on textile finds. Frag- ments of samite found in the grave of Arnegunda and two other female burials (42 and 47) had probably been part of a richly decorated and special veil (Rast-Eicher 2010, 209; Desrosiers/Rast-Eicher 2012, 4).

\section{CONCLUSION}

The gold-plated pins do not belong to frequent finds and based on older finds it is possible to gather 5 examples from Bohemia. It is obvious that the gold-plated pins from Bohemia correspond noticeably with the Thuringian exemplars and not with the examples from other regions. The datable finds from Bohemia, such as Praha-Dejvice, burial no. XIV, and Mochov, burial no. 2, provide a chronological support for the statement that these pins appeared at the turn of $5^{\text {th }}$ and $6^{\text {th }}$ c., i.e. phase E1 or Schmidt's phase IIb, which in Czech archaeological nomenclature wields the epithet 'Thuringian phase' (Droberjar 2008; Schmidt 1961, 173; Svoboda 1965, 224-227). Moreover, it is apparent, that the goldplated iron pins are mostly not preserved in their original length, because the iron part deteriorated. The average length of the Bohemian finds is $7.55 \mathrm{~cm}$, whereas the bronze, silver or golden pins are usually $14-15 \mathrm{~cm}$ long. A good example of that is the golden pin from burial no. 41 at Erfurt-Gispersleben, which is $15.9 \mathrm{~cm}$ long. It is obvious that tapered, corded end is in fact the head part of the pin and not the lower end. In that conception, the not-preserved iron part of pin from Praha-Dejvice, pictured in older photographs (Urbanová/Kostka/Korený 2010, fig. 2) makes sense and the reconstruction of the pin from Chotěšice with a knob-like head is incorrect.

The pin finds represent an important archaeological source for understanding the female costume development during the Great Migration Period. The function of these pins as a hair decoration is supported by applying the gold plating technique, so the item is too fragile to use for ordinary cloth fastening. Similar pins were found next to the head of the deceased, so the original function as hair decoration can be logically derived. Solitary hair pins were used exclusively by women and were used in Frankish, Baiuvaric, Alemannic, Thuringian and Langobardic area. The gold or gilded examples belong to rare finds and in the majority of cases were found in elite graves. During the $7^{\text {th }} \mathrm{c}$., the function of longer pins had changed and examples where longer pins were used for cloth fastening are known.

\footnotetext{
9 The combination of two hair pins is well known from Langobardic graves to the end of the $6^{\text {th }} \mathrm{c}$. and consequently this fashion habit appeared in the Frankish/Alemannic area (Möller 1982, 18).

${ }^{10}$ In the $5^{\text {th }} \mathrm{c}$. there are examples where a pair of short pins was found in the chest or shoulder area used as replacement for fibulas. Their distribution spreads from the Carpathian Basin and Pannonia through the south-west Germany to North Africa and can be dated to the $2^{\text {nd }}$ third of the $5^{\text {th }}$ c. (Quast 2005, 262-269; Rácz 2016, 315, 316).
} 


\section{FINDS CATALOGUE}

\section{Tehov u Říčan, Prague-East distr.}

Discovery background: a metal detector find of Tomáš Štefka in the 'Jedlice' wood, 11. 6. 2020, loose find at GPS 49.9750228 N, 14.7176167 E (WGS-84).

Lenght: $96 \mathrm{~mm}$.

Inventory no.: H1-471975, National Museum, Prague.

\section{Mochov, Prague-East distr.}

Discovery background: rescue excavations 1955-1958 at the site 'U starého Dvora', ransacked female grave no. 12. Other grave finds: a silver gilded S-shaped fibula with bird heads, a clay deep bowl, two groove-ornamented ceramic sherds, a fragment of an iron knife, parts of two three-layered bone/antler combs, a bronze ring. Lenght: $77 \mathrm{~mm}$.

Literature: Svoboda 1965, 188, fig. 45: 7, pl. LXXI: 8; Zeman 1958, 436, 437, 462, fig. 14; 25: 4.

Inventory no.: H1-117165, National Museum, Prague.

\section{Praha-Dejvice, distr. Capital City of Prague}

Discovery background: female grave no. XIV excavated by J. A. Jíra 22. 12. 1893 in brickworks of V. Mailbeck, partially robbed.

Other grave finds: a clay dished pot, a chicken egg, a silver gilded fibula of Straß type, two bronze rings, a bronze ring with 7 knobs, a glass ring, Cypraea shell, three iron sticks (with textile imprints), rounded iron object with rivets, an iron axis of folding chair, an iron weaver sword, an iron cotter pin with a loop, a white stone bead, a silver terminal mounting from a knife sheath, a clay spindle whorl.
Lenght: $50 \mathrm{~mm}$.

Literature: Hlava 2010, 462, 463, fig. 6; Preidel 1930, 298, 299, fig. 333b; Svoboda 1965, 188, pl. XLII: 9; Urbanovál Kostka/Korený 2010, 371, 372, fig. 4: 6.

Inventory no.: P 352 (A 591), Prague City Museum.

\section{Chotěšice, Nymburk distr.}

Discovery background: belongings of partially destroyed grave no. 1 rescued by J. Hellich during construction of a road between villages Chotěšice and Malá Strana in 1912.

Other grave finds: a clay jug with a polished and engraved ornamentation, covered with a small clay cup, two bigger and three small clay beads.

Lenght: $79 \mathrm{~mm}$ (88 $\mathrm{mm}$ with a cap).

Literature: Hellich 1919, fig. 9: 1, 2; Preidel 1930, 298, 299 , fig. 333: a; Svoboda 1965, 188, 241, 242, fig. 34.

Inventory no.: MK 3851 (old nr. 1284), Polabí Museum in Poděbrady.

\section{Prague-Ruzyně, distr. Capital City of Prague}

Discovery background: rescue excavations performed by Prague City Museum and Labrys, o.p.s. in 2003, 2006 and 2007-2008 in the area of Karlovarská Business Park (building D and E), site at the northern shore bench of Litovice stream, a pin found in a circular ditch dated to the Late Bronze Age.

Other finds: isolated sherds of Early Migration Period Lenght: $31 \mathrm{~mm}$

Literature: Kuchař́k et al. 2008, 206, 224, fig. 10: 7. Inventory no.: unknown.

\section{BIBLIOGRAPHY}

Aufderhaar 2009 - I. Aufderhaar: From the goldsmith's point of view: gilding on metals during the first millennium $\mathrm{AD}$ - techniques and their development in the Germanic area. ArchaeoSciences, revue d'Archéométrie 33, 2009, 243-253.

DOI: https://doi.org/10.4000/archeosciences.2269

Babucke 1997 - V. Babucke: Nach Osten bis an den Lech. Zur alamannischen Besiedlung der westlichen Raetia secunda. In: K. Fuchs/M. Kempa/R. Redies/B. TheuneGroßkopf/A. Wais (Hrsg.): Die Alamannen. Stuttgart 1997, 249-260.

Beckmann 1966 - B. Beckmann: Studien über die Metallnadeln der römischen Kaiserzeit im freien Germanien. Saalburg-Jahrbuch 23, 1966, 5-100.

Böhme 1974 - H. W. Böhme: Germanische Grabfunde des 4. bis 5. Jahrhunderts zwischen unterer Elbe und Loire. Studien zur Chronologie und Bevölkerungsgeschichte. Münchner Beiträge zur Vor- und Frühgeschichte 19. München 1974.

von Carnap-Bornheim 1994 - C. von Carnap-Bornheim: Zur Entwicklung des germanischen Gold- und Silberschmiedehandwerks vor und nach den Markomannenkriegen - Vergoldung, Filigran und Pressblech. In: H. Friesinger/J. Tejral/A. Stuppner (Hrsg.): Markomannenkriege. Ursachen und Wirkungen. Spisy Archeologického ústavu AV ČR Brno 1. Brno 1994, 99-107.

Dannheimer 1962 - H. Dannheimer: Die germanischen Funde der späten Kaiserzeit und des frühen Mittelalters in Mittel- franken. Germanische Denkmäler der Völkerwanderungszeit. Serie A 6. Berlin 1962.

Dannheimer 1998 - H. Dannheimer: Das baiuwarische Reihengräberfeld von Aubing, Stadt München. Monographien der Prähistorischen Staatssammlung München 1. Stuttgart 1998.

Desrosiers/Rast-Eicher 2012 - S. Desrosieres/A. Rast-Eicher: Luxurious Merovingian Textiles Excavated from Burials in the Saint Denis Basilica, France in the $6^{\text {th }}-7^{\text {th }}$ Century. In: Textiles and Politics: Textile Society of America $13^{\text {th }}$ Biennial Symposium Proceedings 675. Washington, DC 2012, 1-8.

Droberjar 2001 - E. Droberjar: Zlatý náramek typu Tournai-Blučina ze středních Čech. Archeologie ve středních Čechách 5, 2001, 517-527.

Droberjar 2008 - E. Droberjar: Thüringische und langobardische Funde und Befunde in Böhmen. Zum Problem der späten Phasen der Völkerwanderungszeit. In: J. Bemmann/M. Schmauder (Hrsg.): Kulturwandel in Mitteleuropa. Langobarden - Awaren - Slawen. Akten der Internationalen Tagung in Bonn vom 25. bis 28. Februar 2008. Kolloquien zur Vor- und Frühgeschichte 11. Bonn 2008, 229-248.

Droberjar 2013 - E. Droberjar: Gold und Elite des 5. Jahrhunderts in Böhmen. In: M. Hardt/O. Heinrich-Tamáska (Hrsg.): Macht des Goldes, Gold der Macht. Forschungen zu Spätantike und Mittelalter 2. Weinstadt 2013, 281-294. 
Geisler 1998 - H. Geisler: Das frühbairische Gräberfeld Straubing-Bajuwarenstraße I. Katalog der archäologischen Befunde und Funde. Tafelband. Internationale Archäologie 30. Rahden/Westf. 1998.

Gutsmiedl-Schümann 2014 - D. Gutsmiedl-Schümann: Vom kleinen Mädchen zur jungen Frau. Rekonstruktionen von Lebensabschnitten weiblicher subadulter Individuen auf Grund von archäologischen Funden aus merowingerzeitlichen Gräbern der Münchner Schotterebene. In: S. Moraw/A. Kieburg (Hrsg.): Mädchen im Altertum/Girls in Antiquity. Frauen - Forschung - Archäologie 11. Münster 2014, 417-430.

Hellich 1919 - J. Hellich: Merovejské hroby z Chotěšic. Památky archeologické 31, 1919, 32-35.

Hlava 2010 - M. Hlava: Zlato v Jírově sbírce. Archaeologica Pragensia 20, 2010, 458-477.

Korený 2008 - R. Korený: Merowingerzeitliche Hügelbestattungen in Böhmen. Fines Transire 17, 2008, 107-126.

Kuchařík et al. 2008 - M. Kuchařík/M. Bureš/I. Pleinerová/ J. Jiřík: Nové poznatky k osídlení západního okraje Prahy v 5. století. In: E. Droberjar/B. Komoróczy/ D. Vachůtová (eds.): Barbarská sídliště. Chronologické, ekonomickéa historické aspekty jejich vývoje ve světle nových archeologických výzkumù (Archeologie barbarů 2007). Spisy Archeologického ústavu AV ČR Brno 37. Brno 2008, 201-232.

La Baume 1967 - P. La Baume: Das fränkische Gräberfeld von Junkersdorf bei Köln. Die fränkische Altertümer des Rheinlandes 3. Berlin 1967.

Losert 2003 - H. Losert: Teil I. Das frühmittelalterliche Gräberfeld von Altenerding in Oberbayern und die »Ethnogenese« der Bajuwaren. In: H. Losert/A. Pleterski: Altenerding in Oberbayern. Struktur des frühmittelalterlichen Gräberfeldes und »Ethnogenese der Bajuwaren. Berlin - Bamberg - Ljubljana 2003, 5-499.

Martin 1991 - M. Martin: Tradition und Wandel der fibelgeschmückten frühmittelalterlichen Frauenkleidung. Jahrbuch des Römisch-Germanischen Zentralmuseums Mainz 38, 1991, 629-680.

Martin 1995 - M. Martin: Schmuck und Tracht des frühen Mittelalters. In: M. Martin/J. Prammer (Hrsg.): Frühe Baiern im Straubinger Land. Straubing 1995, 40-71.

Martin 2002 - M. Martin. „Mixti Alamannis Suevi“? Der Beitrag der alamannischen Gräberfelder am Basler Rheinknie. In: J. Tejral (Hrsg.): Probleme der frühen Merowingerzeit im Mitteldonauraum. Spisy Archeologického ústavu AV ČR Brno 19. Brno 2002, 195-223.

Menghin/Springer/Wamers 1987 - W. Menghin/T. Springer/ E. Wamers (Hrsg.): Germanen, Hunnen und Awaren. Schätze der Völkerwanderungszeit. Ausstellungskatalog. Nürnberg 1987.

Merkel 2004 - M. Merkel: Das frühmittelalterliche Gräberfeld von Altheim, Stadt Blieskastel, Saar-Pfalz-Kreis. Dissertation zur Erlangung des Doktorgrades der Mathematisch-Naturwissenschaftlichen Fakultät der Christian-Albrechts-Universität zu Kiel. Kiel 2004.

Möller 1982 - J. Möller: Zur Funktion der Nadel in der fränkisch-alamannischen Frauentracht. Jahrbuch des Römisch-Germanischen Zentralmuseums Mainz 23-24, 1982, 14-53.

DOI: https://doi.org/10.11588/jrgzm.1976.0.47373

Natuniewicz-Sekuła 2017 - M. Natuniewicz-Sekuła: The Craft of the Goldsmith in Wielbark Culture in the Light of the Finds from the Cemetery at Weklice, Elblacg
Commune and Other Necropolis of Roman Period from Elbląg Heights. Technological Studies of Selected Aspects. Sprawozdania Archeologiczne 69, 2017, 185-233. DOI: https://doi.org/10.23858/SA69.2017.008

Natuniewicz-Sekuła 2019 - M. Natuniewicz-Sekuła: The Craft of the Goldsmith in the Society of the Wielbark Culture from the Roman Period - case study of the cemetery at Weklice. In: A. Cieśliński/B. Kontny (eds.): Interacting Barbarians. Contacts, Exchange and Migrations in the First Millennium AD. Neue Studien zur Sachsenforschung 9. Warszawa - Braunschweig - Schleswig 2019, 297-308.

Neuffer-Müller/Ament 1973 - Ch. Neuffer-Müller/H. Ament: Das fränkische Gräberfeld von Rübenach. Die fränkische Altertümer des Rheinlandes 7. Berlin 1973.

Preidel 1930 - H. Preidel: Die germanischen Kulturen in Böhmen und ihre Träger, Erster Band: Die Kulturen. Kassel Wilhelmshöhe 1930.

Quast 2005 - D. Quast: Völkerwanderungszeitliche Frauengräber aus Hippo Regius (Annaba/Bône) in Algerien. Jahrbuch des Römisch-Germanischen Zentralmuseums Mainz 52, 2005, 237-315.

Quast 2013 - D. Quast: Ein kleiner Goldhort der jüngeren römischen Kaiserzeit aus Černivci (ehem. Czernowitz/ Cernăuți) in der westlichen Ukraine nebst einigen Anmerkungen zu goldenen Kolbenarmringen. In: M. Hardt/O. Heinrich-Tamáska (Hrsg.): Macht des Goldes, Gold der Macht. Herrschafts- und Jenseitspräsentation zwischen Antike und Frühmittelalter im mittleren Donauraum. Forschungen zu Spätantike und Mittelalter Band 2. Akten des 23. Internationalen Symposiums der Grundproblemeder frühgeschichtlichen Entwicklung im mittleren Donauraum. Tengelic, 16.-19. 11. 2011. Weinstadt 2013, 171-186.

Rácz 2016 - Z. Rácz: Zwischen Hunnen- und Gepidenzeit. Frauengräber aus dem 5. Jahrhundert im Karpatenbecken. Acta Archaeologica Academiae Scientiarum Hungaricae 67, 2016, 301-359. DOI: https://doi.org/10.1556/072.2016.67.2.6

Rast-Eicher 2010 - A. Rast-Eicher: Garments for a queen first results of the new investigation on the merowingian grave of Queen Arnegundis. In: E. Andersson Strand/M. Gleba/U. Mannering/Ch. Munkholt/ M. Ringgaard (eds): North European Symposium for Archaeological Textiles X, Symposium in May 2008 in Copenhagen. Oxford 2010, 208-210.

Rupp 2005 - C. Rupp: Das langobardische Gräberfeld von Nocera Umbra: 1. Katalog und Tafeln. Richerche di Archeologia Altomedievale e Medievale 31. All'Insegna del Giglio 2005.

Schmidt 1961 - B. Schmidt: Die späte Völkerwanderungszeit in Mitteldeutschland. Veröffentlichungen des Landesmuseums für Vorgeschichte in Halle 18. Halle (Saale) 1961.

Schmidt 1970 - B. Schmidt: Die späte Völkerwanderungszeit in Mitteldeutschland. Katalog (Südteil). Veröffentlichungen des Landesmuseums für Vorgeschichte in Halle 25. Berlin 1970.

Schmidt 1976 - B. Schmidt: Die späte Völkerwanderungszeit in Mitteldeutschland. Katalog (Nord- und Ostteil). Veröffentlichungen des Landesmuseums für Vorgeschichte in Halle 29. Berlin 1976.

Svoboda 1965 - B. Svoboda: Čechy v době stěhování národů. Monumenta Archaeologica Tomus XIII. Praha 1965. 
Tejral 2002 - J. Tejral: Beiträge zur Chronologie des langobardischen Fundstoffes nördlich der mittleren Donau. In: J. Tejral (Hrsg.): Probleme der frühen Merowingerzeit im Mitteldonauraum. Spisy Archeologického ústavu AV ČR Brno 19. Brno 2002, 313-358.

Tejral/Peters/Loskotová 2011 - J. Tejral/D. Peters/Z. Loskotová (Hrsg.): Langobardische Gräberfelder in Mähren I. Spisy archeologického ústavu AV ČR v Brně 39. Brno 2011.

Timpel 1980 - W. Timpel: Das altthüringische Wagengrab von Erfurt-Gispersleben. Alt-Thüringen 17, 1980, 181-238.

Tomka 2005 - P. Tomka: Langobardenforschung in Nordwestungarn. In: W. Pohl/P. Erhart (Hrsg.): Die Langobarden. Herrschaft und Identität. Forschungen zur Geschichte des Mittelalters 9. Wien 2005, 247-264.

Manuscript accepted 13. 7. 2021

Translated by Viktoria Čist’akova, Zdeněk Beneš, Josef Souček

Mgr. Viktoria Čistakovo

Oddělení pravěku a antického starověku

Historické muzeum, Národní muzeum

Václavské náměstí 68

CZ - 11579 Praha 1

viktoria.cistakova@nm.cz
Urbanová 2015 - K. Urbanová: Nové národy na obzoru nová móda. Hroby barbarů v Praze Zličíně. In: J. Jiřík/ J. Vávra/M. Šmolíková/M. Kuchařík a kol.: Hroby barbarů v Praze Zličíně. Svět živých a mrtvých doby stěhování národů. Praha 2015, 207-219.

Urbanová/Kostka/Korený 2010 - K. Urbanová/M. Kostka/ R. Korený: Neznámý známý hrob z Prahy-Dejvic-Podbaby. Archaeologica Pragensia 20, 2010, 361-392.

Werner 1962 - J. Werner: Die Langobarden in Pannonien. Beiträge zur Kenntnis der langobardischen Bodenfunde vor 568. Bayerische Akademie der Wissenschaften. Philosophischhistorische Klasse. Abhandlungen. Neue Folge 55 A. München 1962.

Zeman 1958 - J. Zeman: Pohřebiště z doby stěhování národů v Mochově. Památky archeologické 49, 1958, 423-471.

Mgr. Zdeněk Beneš

Ústav archeologické památkové péče středních Čech Nad Olšinami 448/3

CZ - 10000 Praha 10

zdenek.benes@uappsc.cz 